\title{
MASS MIGRATION AND CRISIS MANAGEMENT OF THE PUBLIC ADMINISTRATION OF THE SLOVAK REPUBLIC
}

\author{
Stanislav Filip \\ School of Economics and Management in Public Administration, Bratislava \\ Slovak Republic
}

CMESTE

JEL Category: K37, K38, H12

\begin{abstract}
Author of this article analyses the current state of a readiness of the crisis management in the public administration of the Slovak Republic to deal with potential crisis situations caused by the massive influx of the illegal migrants to the city or town areas. Introduction of the article defines the theoretical framework of migration issue proposing the possible scenarios from threats of the own citizens and territories occupies by illegal migrants. It analyzes the current legal procedures of the crisis management of the public administration and its cooperation with non-governmental organizations to solve the social crisis. At the end of the article, the author presents the possible solutions for the training of staff and equipment of the rescue and security units to improve their readiness for real solution to the social crisis.
\end{abstract}

Keywords: immigration policy, crisis scenarios, crisis management, public administration

\section{INTRODUCTION}

Since the outbreak of the illegal and uncontrollable immigration influx from Syria, Libya, Afghanistan and North African area to Europe, Slovakia has proved to be one of the most active members among states of the European Union in terms of the search for solutions how to eliminate the safety risk of civilians and land. Terrorist attacks, violence, and crimes against property are the primary reasons leading EU representatives and member states to adopt measures necessary to

Address of the author:

Stanislav Filip

棒: stanislav.filip@vsemvs.sk sustain a public security as state Ujvary (2016) and Filipova (2016). To reinforce the Schengen border security, particularly the southern borderline comprising Italian border, immigration controls are being tightened up, countries are searching for possibilities to unite and simplify the asylum process. Under these circumstances, Refugee agreement between EU and Turkey surpasses other measures taken with the financial support of EU.

Slovak Republic as one of the most active EU member has demonstrated its will to maintain the state border protection with Hungary, Macedonia, and Slovenia through various activities with the support of police forces. Slovak government has 
taken several legislative and organizational measures regarding the protection of own citizens, economy and state territory to reduce the security risk as state Vaysilova, Georgiev (2016) including the law adjustment, the state border protection reinforcement and the military exercise of the Slovak Armed Forces and Slovak Police Forces in collaboration with neighboring state forces as well.

Less attention seems to be paid towards the preparation of the state administration authorities regarding hypothetical admission of a vast number of illegal immigrants during their transit to Western Europe and therefore it is the major topic of this article. Its main aim is to analyze and evaluate the current level of emergency management of the state authorities in the case of crisis, to define crisis scenarios and to suggest the possible outputs to improve the civilian protection and manners how to provide more efficient humanitarian aid to immigrants.

The aim of this article is to provide the better public perspective of the current alertness of the public authorities to resolve the crisis caused by the unexpected influx of refugees into the territory of towns and municipalities of Slovak Republic, to identify the expenses and deficiencies of the current situation and to draft the possible solutions.

Qualitative and quantitative methods of the scientific research were applied, such as the method of the scientific abstraction and description, methods of the analysis and synthesis, the mathematical statistics as indicated Filip, Filipova (2016), also the comparative method and the method of the scientific induction and deduction.

\section{THEORETICAL CONCEPTS AND FRAMEWORK OF MIGRATION ISSUES}

Accurate term definition is necessary within right comprehension of topic discussed therefore we choose only the terms and definitions directly related to the topic of the article and in accordance with ("Act of the National Council of Slovak Republic No 480/2002 Coll. on asylum as later amended") and from Dictionary of terms of crisis management as indicated Simak (2005).
Migrant is any person who is moving or has moved across an international border to the country where he or she was not born to ensure the better living condition for family and his/her own being.

An immigrant is a person migrating to another country with the intent to settle down. A refugee is a person who has been forced to flee his or her country of origin or country of residence because of persecution, war, disturbing public order or violence.

Asylum is a protection granted to the foreigner from persecution because of reasons stated in The Convention Relating to the Status of Refugees. (severe or repeated significant breach of Human rights).

Complementary protection is a protection against serious injustice in the country of origin.

Migration is a movement of person or group of people within the geographical and social area, temporary or permanent residence change (international, local).

Legal migration means boundary line crossing with the valid travel documents or with a valid visa and permit required to enter the country. Illegal migration is the unauthorized crossing of the border without valid travel documents, visa and residence permit or unauthorized stay in the territory of the specific country after the expiration of documents, visa or residence permit.

\section{ANALYSIS OF CURRENT STATE OF MIGRATION IN SLOVAKIA}

The current situation of the illegal migration within the European Union is perceived by Slovak authorities as a security risk with the potential to evolve under such conditions into the security threat. By the end of 2017, the EU has admitted 705705 of immigrants, with the highest number registered in Germany (222 thousand) and France (99 300). According to the statistics of Eurostat, Slovak Republic has admitted 330 immigrants throughout years 2014 and 2015, in the year 2016 only 145 and at the end of 2017 also only 160, what is the minimum in whole EU. The development of immigrants' influx within the whole $\mathrm{EU}$ and the chosen member states of EU during the years 2008 and 2017 is given in table 1. 
Table 1 The development of immigrants' influx within the whole EU and the chosen member states of EU by years from 2008 to 2017

\begin{tabular}{|l|r|r|r|r|r|r|}
\hline Country & \multicolumn{1}{c|}{$\mathbf{2 0 0 8}$} & \multicolumn{1}{c|}{$\mathbf{2 0 1 2}$} & \multicolumn{1}{c|}{$\mathbf{2 0 1 4}$} & \multicolumn{1}{c|}{$\mathbf{2 0 1 5}$} & \multicolumn{1}{c|}{$\mathbf{2 0 1 6}$} & \multicolumn{1}{c|}{$\mathbf{2 0 1 7}$} \\
\hline EU (28) & 226330 & 309820 & 627780 & 1322190 & 1260910 & 705705 \\
\hline Germany & 26945 & 77650 & 202815 & 476620 & 745155 & 222560 \\
\hline France & 41845 & 61455 & 64310 & 75750 & 84270 & 99330 \\
\hline England & 31695 & 28895 & 33820 & 39000 & 39735 & 33780 \\
\hline Belgium & 15940 & 28285 & 22850 & 44760 & 18280 & 18340 \\
\hline Hungary & 3175 & 2155 & 42775 & 177135 & 29430 & 3390 \\
\hline $\begin{array}{l}\text { Czech } \\
\text { Republic }\end{array}$ & 1650 & 755 & 1155 & 20365 & 1475 & 1445 \\
\hline Poland & 8515 & 10755 & 8025 & 12190 & 12305 & 5045 \\
\hline Slovakia & 905 & 730 & 330 & 330 & 145 & 160 \\
\hline
\end{tabular}

Source: (Eurostat, 2018)

Table 2 Development of asylum seeker number in Slovakia since 1993 to 2003.

\begin{tabular}{|l|r|l|r|r|r|r|}
\hline Year & $\begin{array}{l}\text { Number of } \\
\text { applicants }\end{array}$ & $\begin{array}{l}\text { Asylum } \\
\text { granted }\end{array}$ & $\begin{array}{l}\text { Asylum } \\
\text { denied }\end{array}$ & $\begin{array}{l}\text { Provided } \\
\text { protection }\end{array}$ & $\begin{array}{l}\text { Interrupted } \\
\text { procedures }\end{array}$ & $\begin{array}{l}\text { Granting } \\
\text { citizenship }\end{array}$ \\
\hline 1993 & 96 & 41 & 20 & 0 & 25 & 0 \\
\hline 1994 & 140 & 58 & 32 & 0 & 65 & 0 \\
\hline 1995 & 359 & 80 & 57 & 0 & 190 & 0 \\
\hline 1996 & 415 & 72 & 62 & 0 & 193 & 4 \\
\hline 1997 & 645 & 69 & 84 & 0 & 539 & 14 \\
\hline 1998 & 506 & 53 & 36 & 0 & 224 & 22 \\
\hline 1999 & 1320 & 26 & 176 & 0 & 1034 & 2 \\
\hline 2000 & 1556 & 11 & 123 & 0 & 1366 & 0 \\
\hline 2001 & 8151 & 18 & 130 & 0 & 6154 & 11 \\
\hline 2002 & 9743 & 20 & 309 & 0 & 8053 & 59 \\
\hline 2003 & 10358 & 11 & 531 & 0 & 10656 & 42 \\
\hline
\end{tabular}

Source: (MV SR, 2018)

According to the data of the Bureau of Borderline and Alien Police (Statistical Overview of Legal and llegal Migration in the Slovak Republic, 2017) number was subsequently increasing up to the end of the year. By the end of 2017, Slovakia had reported the sixth lowest number of foreign citizens among all EU states, with 104,451 foreigners granted by residence permit living in Slovak territory. Countries with lower share are only Lithuania, Croatia, Romania, Bulgaria and Poland. EU citizens represent $51.7 \%$ of the total number of foreigners reportedly in our territory with most citizens from the Czech Republic. Table 2 provides a data regarding the historical development of immigrants' influx into the territory of Slovak Republic since 1993 to 2003

Data given in the table indicates that Slovakia was not been an attractive country for asylum seekers right after the independence establishment. The situation has changed after admission process to EU with the number of applicants increased to 10358. Due to strict criteria, only 11 people were granted the asylum permit. The accession of Slovak Republic to the EU commenced an 
interesting progress regarding applicants for asylum when a number of applicants dropped from 11000 of immigrants in 2004 to 909 after the accession to Schengen and tightening of control at the outer borderline with Ukraine followed by 331 applications in 2014 and 330 in 2015 . By the end of 2017, only 166 applications for asylum were submitted [10]. To sum it up, since the constitution

Table 3 Development of asylum seeker number in Slovakia since 2004 to 22. April 2018.

\begin{tabular}{|l|r|r|r|r|r|r|}
\hline Year & $\begin{array}{c}\text { Number of } \\
\text { applicants }\end{array}$ & \multicolumn{1}{|c|}{$\begin{array}{c}\text { Asylum } \\
\text { granted }\end{array}$} & $\begin{array}{c}\text { Asylum } \\
\text { rejected }\end{array}$ & $\begin{array}{c}\text { Provided } \\
\text { /unprovided } \\
\text { protection }\end{array}$ & $\begin{array}{c}\text { Interrupted } \\
\text { process }\end{array}$ & $\begin{array}{c}\text { Granted } \\
\text { citizenship }\end{array}$ \\
\hline 2004 & 11395 & 15 & 1592 & 0 & 11782 & 20 \\
\hline 2005 & 3549 & 25 & 827 & 0 & 2930 & 2 \\
\hline 2006 & 2849 & 8 & 861 & 0 & 1940 & 5 \\
\hline 2007 & 2642 & 14 & 1177 & $82 / 646$ & 1693 & 18 \\
\hline 2008 & 909 & 22 & 416 & $66 / 273$ & 457 & 4 \\
\hline 2009 & 822 & 14 & 330 & $98 / 165$ & 460 & 1 \\
\hline 2010 & 541 & 15 & 180 & $57 / 101$ & 361 & 3 \\
\hline 2011 & 491 & 12 & 186 & $91 / 47$ & 270 & 7 \\
\hline 2012 & 732 & 32 & 334 & $104 / 153$ & 383 & 0 \\
\hline 2013 & 441 & 15 & 124 & $34 / 49$ & 352 & 7 \\
\hline 2014 & 331 & 14 & 197 & $99 / 41$ & 163 & 12 \\
\hline 2015 & 330 & 8 & 124 & $41 / 24$ & 148 & 5 \\
\hline 2016 & 146 & 167 & 82 & $12 / 13$ & 35 & 3 \\
\hline 2017 & 166 & 29 & 77 & $25 / 26$ & 73 & 6 \\
\hline 2018 & 49 & 1 & 34 & $5 / 4$ & 16 & 0 \\
\hline $\begin{array}{l}\text { Total } \\
\text { since } \\
1993\end{array}$ & 58682 & 850 & 8101 & $714 / 1532$ & 49562 & 247 \\
\hline
\end{tabular}

Source: (MV SR, 2018)

Bureau of Borderline and Aliens Police reports cases of illegal migration to SR every year despite the accession to Schengen and tightening of outer borderline with Ukraine. According to the annual reports of the Bureau, more than 1100 immigrants have illegally crossed state and airport borderline so far. The number rose in 2014 and 2015 due to the European migrant crisis. In 2015 there were 2 535 foreigners, 2016 more than 2170 crossed the borderline or stayed in the territory unauthorized. At the end of the year 2017, the number was 2706 . Regarding nationality of illegal immigrants, the majority are Ukraine (1786), Serbia (227), Viet Nam (160), followed by Iraq (108), Afghanistan (34) etc. and another 48 countries of North America, Africa, Asia and Indonesia. Development of the illegal migration in SR from 2011 to 2017 is stated in fig. 1. of the Slovak Republic in 1993 to the end of 2017 only 850 asylum applicants were granted permit of the total number of 58682 representing $1.44 \%$ of total share. Lack of interest of asylum applicants reflects such facts. Development of a number of the asylum applicants in the period between 2004 and 22 of April 2018 is stated in the table. 3.

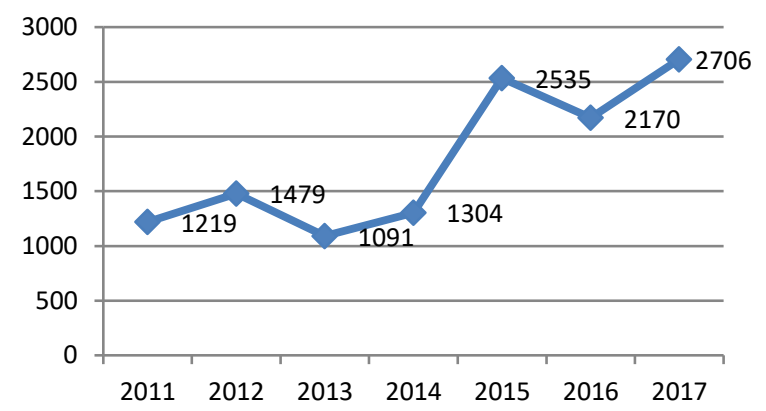

Fig. 1 Development of illegal migration in Slovakia since 2011 to 2017

Source: (MV SR, 2018)

In conclusion, we can sum up, that stated data of legal but primarily illegal immigration in the Slovak Republic do not represent a security threat, even though it might represent the security risk requiring consistent concern of the authorities and the 
executive security services of the public administration to prevent the occurrence of the security threat or crisis

\section{SCENARIO OF POTENTIAL THREAT TO TERRITORY OF TOEN/MUNICIPALITY DUE TO MASS IMMIGRATION}

Therefore, we can presume traffic and railway junctions with a connection to Austria and the Czech Republic to obtain the highest level of concern in the case of the mass immigrant influx.

Main railway station in Bratislava, district of Stare Mesto or railway station in Petrzalka with direct connections to Austria located in Petrzalka district is very likely to become places of the mass immigration gathering.

Anticipated structure of immigration groups includes men, women, and children of all ages, various religions with dominant Islamic belief. Physical and psychic exhaustion together with the state of health immigrants might cause a potential security risk to the civilians living in districts mentioned above and the passengers in traffic junctions. Physical abuse, looting, movement obstruction must be considered as well as the highest possibility of the terrorist attack or transmission of exotic diseases such as HIV, tuberculosis, hepatitis type B and C. Transmission of scabies and lice is also very likely due to the contamination of public places, garbage accumulation etc.

Inevitable measures required to eliminate the security risk and to prevent the security threat or crisis are:

- protection of own civilians and movement regulation in places of cumulation of migrants (Police department, Municipal police in cooperation with Slovak Armed Forces)

- protection of immigrants against Slovak extremists' assaults (Police department, Municipal police in cooperation with Slovak Armed Forces)

- basic needs of immigrants (food, beverages, medical aid, warm, clothes, emergency accommodation, toilets, waste)

- translation / interpreting

- psychological help
- transport of the people to the country of destination or a refugee camp in Humenne or accommodation camps in Opatovska Nova Ves and Rohovce

\section{- medical help}

Accurate management of measures assumes a necessity to answer the main questions:

- What kind of protection are we able to provide to own inhabitants and how?

- What kind of humanitarian aid are we able to provide to immigrants and how?

\section{EVALUATION OF CURRENT STATE OF PROCEDURES OÍF CITY DISTRICT/MUNICIPALITY REGARDING SOLUTION TO AN EMERGENCY}

Steps and measures required in a case of emergency due to the mass influx of illegal immigrants to the area of city district or municipality should include the preparation part, declaration of the emergency, solution of the crisis itself and reparation of damaged system and land.

\section{Preparation part includes:}

- to summon the task force of city district/municipality under the threat of mass gathering of immigrants

- send a request for emergency team to relevant district office Ministry of the Interior of the Slovak Republic Decree No 523/2006, Coll.

- summon the representatives of Ministry of Interior of the Slovak Republic, Immigration Bureau of SR, Bureau of borderline and aliens police, Public transport company of Bratislava, Railways of the Slovak Republic, Health service

- invite non-governmental humanitarian organizations and charities.

The debate over the preparation of crisis solutions

- public warning system and notifying security forces

- determination of the appropriate premises for immigrants to cumulate

- personal security system (civilians protection, rescue team, humanitarian aid)

- medical services (National Health services)

- material supply 
- financial provision - solution expenses

- communication system

- media support.

Declaration of the emergency situation is realized under the condition of increasing number of illegal immigrants in reserved premises and is decelerated by authorities in the question of the relevant district in compliance with the ("Act of the National Council of Slovak Republic No 42/1994 Coll. on civilian protection"). It is likely to assume that crisis situation would be declared by the chief of the district council in question or mayor of city district/municipality. The government of Slovak Republic has the authority to declare the emergency situation on the understanding of the terroristic threat or the vast public danger.

Besides the declaration of the emergency, there is a necessity to warn public and demand the cooperation of emergency and security services.

All measures during the preparation of the emergency are managed by emergency crisis team and comprise:

- organization of rescue operations regarding the current situation and anticipated development of situation (emergency services in cooperation with non-governmental humanitarian organizations),

- own civilians/public protection

- movement of immigration restrictions and protection within the premises

- provision of medical and material aid

- provision of social protection of children and social guardianship

- provision of psychological emergency aid

- transport of immigrants to the refugee camps or countries of destination

In the phase of reparation of damaged and polluted premises, district/municipality in question is using personnel in compliance with ("Act no. 5/2004 Coll. on Employment Services") and funds from own resources and funding from reserved funds from national budget as indicated by Víghova and Stangova (2013).

Emergency situation measures stated above are corresponding with the current jurisdictional state. Despite the higher emergency risk of public threat and territory of Slovak republic within last two years, Slovak government focuses primarily on state borderline protection and terrorist attack prevention.

Crisis management authorities for public administration competent in such question shows lack of preparation regarding emergency crisis management in their territorial plan. The workshop organized in April of 2016 by authorities of city districts of Petrzalka is an example of the positive approach and the active interest of public administration authorities and was carried out as a response to the hypothetical emergency situation caused by the mass illegal influx of immigrants. The aim of the workshop was to propose solutions of the hypothetical emergency situation within the city district of Petrzalka.

Workshop conclusions have revealed some problematic sections of jurisdictional adjustment of the current situation:

- legal regulations do not presume provision of humanitarian aid to the citizens of the third countries in the Slovak Republic

- establishment of the particular public administration on the subject of public health care and labor, social affairs, and family lead to discharging representatives from the management of cities/municipalities and districts emergency teams

- public administration authorities do not express appropriate level of engagement regarding possible cooperation with humanitarian organizations and charities not even during preparation of hypothetical emergency situations. Except for Red Cross representatives, no other non-government organizations are presented at various rescues service exercises of an integrated rescue system.

Suggestions to improve the current state:

- Unconditional adjustment of Act of the National Council of Slovak Republic No 387/2002 Coll. on the Management of State in Crisis Situations Other than a Time of War and State of War

- Workshops and exercises for emergency management authorities of districts with potential security risk occurrence caused by illegal and mass migration

- cooperation improvement of the city districts and municipalities with humanitarian non- 
governmental organizations and charities to protect own citizens and help the citizen of the third countries in the territory of Slovak Republic

- representatives of specialized public administration (Central Office of Labor, Social Affairs, and Family) to be involved in the emergency teams

\section{CONCLUSIONS}

The Slovak Republic declared during the Presidency of the Council of the European Union the issue of illegal and uncontrollable migration its major priority and has adopted a broad range of measures within the 2014 and today regarding protection of state borderline and its citizens against security threat which illegal migration is supposed to present.

The lower focus is set on the preparation of conditions for activities of crisis management authorities of the lowest level of public administration, even though the regional authorities of Bratislava's city districts and surrounding municipalities are the most likely to face the emergency caused by mass immigration influx to their territory.

The aim of this article was accomplished since it provides the analysis of the current migration situation in Slovakia. The article defines the problematic parts in the process of solving emergency situations by public administration authorities and suggests the possible manners of improvement.

\section{WORKS CITED}

Bureau of Borderline and Alien Police. (2017). Statistical Overview of Legal and Illegal Migration in the Slovak Republic. Retrieved from http://www.minv.sk/?rocenky

Cibak, L. (2016). Korruption und ihre gesamtwirtschaftliche Bedeutung, in Kriminalistik-Osterreich, 1/2016, ISBN 978-3-7832-0804-7.

Eurostat. (2018, Mar 30). Asylum and first-time asylum applicants - annual aggregated data (rounded). Retrieved from eurostat: http://appsso.eurostat.ec.europa.eu/nui/show.do?dataset=migr_asyappctza\&lang=en

Filip, S., Filipova, L'. (2016). Statistiky v krizovom manazmente verejnej spravy Slovenska. In: Natural science readings: Abstracts book. Bratislava: Vysoka škola ekonómie a manazmentu verejnej spravy. 2016. ISBN 9788089654253. -pp. 69-72.

Filipova, L. (2016). Sanctions EU against Russian Federation and its imputs on tourism the Eurozone and Slovak Republic. In: Informacijni technologiji, ekonomika ta pravo: stan ta perspektivy rozvytku: Materialy miznarodnoji naukovo-prakticnoji konferenciji molodych vcenich ta studentiv. "Information technologies, economics and law: state and development perspectives": ITEL-2016. - Chernivci. Ukraine.: Knigi - XXI, 2016. - ISBN 9786176141402. - pp. 253-255.

MV SR. (2018, May 24). Statistiky. Retrieved from Ministerstvo Vnutra Slovenskej republiky: http://www.minv.sk/?statistiky-20Siller,H.,

Simak, L., et all. (2005). Dictionary of terms of crisis management. FSI. Zilinska univerzita v Ziline. ISBN 80-88829-75-5. s.44

The act of the National Council of Slovak Republic No 480/2002 Coll. on asylum as later amended

The act of the National Council of Slovak Republic No 42/1994 Coll. on civilian protection

Ujvary, K. (2016). Sicherheitslage hinsichtlich der Migrationswelle in der EU aus Sicht der Slowakischen Republik / aut. Kristian Ujvary. In: MEPA - Fachjournal. - ISSN 2079-3464. - No. 1 (2016), pp. 55-66. 
Vaysilova E., \& Georgiev, N. (2016 May 25-26). Detecting crisis states in the transport company through cost analysis, The Twenty-first International Scientific Conference Crises Situations Solution in the Specific Environment, Zilina, Slovakia. - ISBN 978-80-554-1213-9, 735-740.

Vighova, A., \& Stangova, N. (2013). Information System - Basis for Successful Management of the Organization. International Journal of Advances in Management and Economics. - ISSN 22783369, 8-12.

Received for publication:

09.04 .2018

Revision received:

Accepted for publication:

07.06 .2018

\section{How to cite this article?}

Style - APA Sixth Edition:

Filip, S. (2018, July 15). Mass Migration and Crisis Management of the Public Administration of the Slovak Republic. (Z. Cekerevac, Ed.) MEST Journal, 6(2), 55-62. doi:10.12709/mest.06.06.02.07

Style - Chicago Sixteenth Edition:

Filip, Stanislav. 2018. "Mass Migration and Crisis Management of the Public Administration of the Slovak Republic." Edited by Zoran Cekerevac. MEST Journal (MESTE) 6 (2): 55-62. doi:10.12709/mest.06.06.02.07.

Style - GOST Name Sort:

Filip Stanislav Mass Migration and Crisis Management of the Public Administration of the Slovak Republic [Journal] // MEST Journal / ed. Cekerevac Zoran. - Toronto : MESTE, July 15, 2018. - 2 : Vol. 6. - pp. 55-62.

Style - Harvard Anglia:

Filip, S., 2018. Mass Migration and Crisis Management of the Public Administration of the Slovak Republic. MEST Journal, 15 July, 6(2), pp. 55-62.

Style - ISO 690 Numerical Reference:

Mass Migration and Crisis Management of the Public Administration of the Slovak Republic. Filip, Stanislav. [ed.] Zoran Cekerevac. 2, Toronto : MESTE, July 15, 2018, MEST Journal, Vol. 6, pp. 55-62. 